\title{
A comparison between the ontogeny of two related blenniid species Parablennius gattorugine and Parablennius ruber (Pisces: Blenniidae)
}

\author{
C. FARIA ${ }^{1}$, F. GIL ${ }^{2}$, R.S. SANTOS ${ }^{3}$ AND V.C. ALMADA ${ }^{1}$ \\ ${ }^{1}$ Unidade de Investigação em Eco-Etologia, Instituto Superior de Psicologia Aplicada, R. Jardim do Tabaco 34, P-1149-041 Lisboa, \\ Portugal, ${ }^{2}$ Aquário Vasco da Gama, R. Direita, Dafundo, P-1495 Lisboa, Portugal, ${ }^{3}$ Departamento de Oceanografia e Pescas, \\ Universidade dos Açores, 9901-862 Horta, Azores, Portugal
}

Parablennius gattorugine and Parablennius ruber are closely related sympatric western European species. In this note, traits that distinguish the larvae of both species are presented and it is demonstrated that conflicting descriptions reported in the literature on the larvae of $\mathrm{P}$. gattorugine stem from confusion between the two species.

Keywords: Parablennius gattorugine, Parablennius ruber, larval development

Submitted 4 December 2008; accepted 29 September 2009

\section{INTRDDUCTION}

Parablennius gattorugine (Brünnich, 1768) is widespread from the Mediterranean to boreal Europe (Almada et al., 2001). Parablennius ruber (Valenciennes, 1836) is an eastern Atlantic rocky fish species abundant in the Azores (Santos, 1987; Azevedo \& Homem, 2002), and also recorded on the coast of mainland Europe, from the British Isles to the southern coast of Portugal (Almeida, 1982; Zander, 1986; Wheeler et al., 2004; Goodwin \& Picton, 2007).

These two species are so similar that, for many years, they were not distinguished, until recently when $P$. ruber was revalidated independently by several authors (Almeida, 1982; Bath, 1982; Almada et al., 2007). According to Almada et al. (2007), P. ruber could have evolved from a $P$. gattorugine-like ancestor who colonized the Azores, and the European populations may be originated from occasional larval transport from the Azores population. Parablennius gattorugine and $P$. ruber differ in a number of morphological traits, such as the morphology of the lateral line system and the shape of the orbital tentacules (Almeida, 1982; Bath, 1982; Almada et al., 2007).

The biology of these species has been little studied (Wheeler, 1969; Dunne \& Byrne, 1979; Azevedo \& Homem, 2002) and the information available concerning their developmental biology is scattered and incomplete (e.g. Ford, 1922; Lebour, 1927; Brown, 1929; Fives, 1970; Villegas, 1980; Santos, 1987; Villegas-Ríos et al., 2009). In the case of $P$. gattorugine the descriptions of the morphology of its early life stages are contradictory. While Ford (1922) and Lebour (1927) did not refer to the presence of pre-opercular spines

Corresponding author:

C. Faria

Email: cfaria@ispa.pt in the larvae of $P$. gattorugine, Villegas (1980) refers to these features. Moreover, the distribution of chromatophores reported by Ford (1922) and Lebour (1927) does not agree with the pattern described by Villegas (1980). As the presence of $P$. ruber on western European coasts was generally disregarded until recently, these conflicting reports make us suspect that the different authors were describing larvae of the two species.

For $P$. ruber there is no complete description of its ontogeny. Santos (1987) presented a brief description of the eggs and embryos of this species and Villegas-Ríos et al. (2009) described its embryonic development and some features of newly-hatched larvae.

As an attempt to clarify this issue, in this paper we compared the early life stages of $P$. ruber and $P$. gattorugine based on laboratory-reared fish, kept in controlled conditions.

\section{MATERIALS AND METHODS}

Eggs and larvae were obtained from fish maintained in captivity at a public aquarium, Aquário Vasco da Gama (Lisbon), in 2004-2005 for Parablennius gattorugine (2 males: $14 \mathrm{~cm}$ total length (TL) and $15 \mathrm{~cm}$ TL; 1 female: $13 \mathrm{~cm} \mathrm{TL}$ ) and in 2007-2008 for Parablennius ruber (6 males: 7-12 cm TL; 6 females: $7-12 \mathrm{~cm} \mathrm{TL}$ ). The adults of $P$. gattorugine were collected at mainland Portugal (S. Pedro do Estoril, Cascais $38^{\circ} 419 \mathrm{~N} 09^{\circ} 259 \mathrm{~W}$ ), while the adults of $P$. ruber were collected at the Azores (Faial $38^{\circ} 409 \mathrm{~N} 27^{\circ} 109 \mathrm{~W}$ ), an area where $P$. gattorugine is absent.

Both species were maintained in 600 tanks, illuminated with fluorescent light (6oW) from 9.00 to 18.00 hours, with the bottom covered with a sand layer. Several flat stones were provided as shelter and breeding sites. The time and temperature data of embryonic and larval development for 
each species are given in Table 1. Larvae of both species survived until metamorphosis. Upon hatching larvae were reared in glass 3 ol tanks, illuminated with fluorescent light (18W) 24 hours per day. Larvae were fed two times a day with Brachionus sp. enriched with protein Selco (Artemia Systems) and algae, which were later replaced by decapsulated eggs or nauplii of Artemia sp. Eggs and larvae were collected daily until metamorphosis, anaesthetized (Ethylene Glycol Monophenyl Ether-Merck) and photographed.

\section{RESULTS}

Males guarded egg batches from January to May/June in the case of Parablennius gattorugine and from January to April in the case of Parablennius ruber. In both species the males cared for multiple spawnings. In one nest of $P$. gattorugine, eggs in 6 different developmental stages were observed. In $P$. ruber at least four distinct clutches were guarded simultaneously by a male.

The eggs of both species were semi-spherical and had a flat attachment disc, although those of $P$. gattorugine were larger ( $t$-test for independent samples: $t=9.26, \mathrm{df}=18, \mathrm{~N}=10$ for major axis; $t=14.64, \mathrm{df}=18, \mathrm{~N}=10$ for minor axis) (see Table 2). Recently laid eggs of $P$. gattorugine had an orange coloration, and in subsequent days they became brownish. Those of $P$. ruber were initially whitish and subsequently turned light brown. The eggs of both species presented pinkish lipid droplets.

Although the length of the embryonic period varied with temperature, for the same temperature it was very similar in the two species: $30-33$ days at $13^{\circ} \mathrm{C}$ and $15-16$ days at $18^{\circ} \mathrm{C}$ for $P$. gattorugine, and $14^{-15}$ days at $17^{\circ} \mathrm{C}$ for $P$. ruber.

The time of planktonic life was also very similar, although slightly longer for $P$. gattorugine: 52-66 days for $P$. gattorugine (larvae with $17.0-20.0 \mathrm{~mm} \mathrm{TL}$ ), and 47 days for $P$. ruber (larvae with $15.0-17.0 \mathrm{~mm} \mathrm{TL}$ ). The change to a benthic mode of life was gradual for both species. In the case of $P$. gattorugine fish began to contact the aquarium bottom at $12.0 \mathrm{~mm}$ TL (31 days after hatching), while in the case of $P$. ruber they began to contact the aquarium bottom almost immediately after hatching, although they began to

Table 1. Temperature range of the batches used for embryonic development and for larval development.

\begin{tabular}{|c|c|c|c|c|}
\hline & Mean & Range & SD & $\mathbf{N}$ \\
\hline \multicolumn{5}{|c|}{ (a) Parablennius gattorugine } \\
\hline \multicolumn{5}{|c|}{ Spawning } \\
\hline $26 / 01 / 2005$ & 13.00 & $12.00-14.00$ & 0.74 & 30 \\
\hline $18 / 05 / 2005$ & 18.50 & $17.50-19.50$ & 0.66 & 15 \\
\hline \multicolumn{5}{|l|}{ Hatching } \\
\hline $02 / 03 / 2005$ & 16.00 & - & - & 55 \\
\hline $06 / 05 / 2005$ & 16.00 & - & - & 54 \\
\hline \multicolumn{5}{|c|}{ (b) Parablennius ruber } \\
\hline \multicolumn{5}{|l|}{ Spawning } \\
\hline $02 / 03 / 2007$ & 16.70 & $16.00-17.50$ & 0.41 & 14 \\
\hline $03 / 04 / 2007$ & 17.00 & $16.00-20.00$ & 1.26 & 14 \\
\hline \multicolumn{5}{|l|}{ Hatching } \\
\hline $03 / 03 / 2007$ & 17.00 & $16.50-17.50$ & 0.46 & 30 \\
\hline $04 / 04 / 2007$ & 17.00 & $16.00-18.00$ & 0.43 & 51 \\
\hline $22 / 01 / 2008$ & 18.50 & $17.50-20.00$ & 0.45 & 52 \\
\hline
\end{tabular}

Table 2. Egg size.

\begin{tabular}{|c|c|c|c|c|}
\hline & Mean & Range & SD & $\mathbf{N}$ \\
\hline \multicolumn{5}{|c|}{ (a) Parablennius gattorugine } \\
\hline Major axis & $1.20 \mathrm{~mm}$ & $1.10-1.20 \mathrm{~mm}$ & 0.05 & 10 \\
\hline Minor axis & $1.10 \mathrm{~mm}$ & $1.00-1.10 \mathrm{~mm}$ & 0.05 & 10 \\
\hline \multicolumn{5}{|c|}{ (b) Parablennius ruber } \\
\hline Major axis & $1.10 \mathrm{~mm}$ & $0.90-1.00 \mathrm{~mm}$ & 0.05 & 10 \\
\hline Minor axis & $0.60 \mathrm{~mm}$ & $0.50-0.70 \mathrm{~mm}$ & 0.05 & 10 \\
\hline
\end{tabular}

settle for short periods (up to a few seconds) only at $8.0 \mathrm{~mm}$ TL (26 days after hatching). Gradually they spent longer times at the bottom, until they settled permanently. Most fish still lacked juvenile pigmentation on settling. The settling time obtained for $P$. gattorugine agrees with observations in the field, where the smallest fish collected in tide-pools were $19.0 \mathrm{~mm} \mathrm{TL}(\mathrm{SD}=0.20$, range: $17.0-21.0 \mathrm{~mm}, \mathrm{~N}=30$ ), with some fish still lacking full juvenile pigmentation (C. Faria, personal observations). In the case of P. gattorugine, the fish did not permanently remain on the bottom after settlement. They swam in the entire water column, although the duration of each swimming bout was short (average $=$ 18.32 seconds, $\mathrm{SD}=22.97$, range: $2.00-118.00$ seconds, $\mathrm{N}=31$ ). The time spent in the water column amounted to $31 \%$ of the time a fish was observed.

The developmental sequences of both species are similar (see Tables 3 \& 4). Newly-hatched larvae of P. gattorugine measured $5.20 \mathrm{~mm}$ TL $(\mathrm{SD}=0.07$, range: $5.10-5.30 \mathrm{~mm}$, $\mathrm{N}=10$ ), while those of $P$. ruber measured $4.10 \mathrm{~mm} \mathrm{TL}$ ( $\mathrm{SD}=0.07$, range: $4.00-4.10 \mathrm{~mm}, \mathrm{~N}=10$ ). In both species, the anus and mouth were opened, the lips were formed and the jaws were differentiated. The yolk was almost fully absorbed. The liver was very conspicuous and the eyes were fully pigmented. The opercula were opened and the sagittae and lapilli otoliths were visible. The pectoral fins were small and rounded, without any rays or pigmentation. For both species notochord flexion was completed at $10-12 \mathrm{~mm} \mathrm{TL}$, and all fin rays were fully formed at $13.0 \mathrm{~mm}$ TL $(P$. gattorugine: $\mathrm{D}=\mathrm{XIII}+18-19 ; \quad \mathrm{A}=$ $\mathrm{II}+20 ; \quad \mathrm{V}=\mathrm{I}+3 ; \quad \mathrm{P}=14 ; \quad$. ruber $: \mathrm{D}=\mathrm{XIII}+19-20$; $\mathrm{A}=\mathrm{II}+21 ; \mathrm{V}=\mathrm{I}+3 ; \mathrm{P}=14$ ).

The species may be distinguished by the presence of preopercular spines in P. ruber (two to four spines), which are visible almost from hatching (at $5.0 \mathrm{~mm} \mathrm{TL}$ ) until metamorphosis. These are absent in P. gattorugine.

The pigmentation patterns of both species are similar. The newly-hatched larvae of both species (Figure 1) presented heavy peritoneal pigmentation and an internal row of melanophores from behind the eyes to the gut. The head of both species presented dorsally some diffuse yellowish pigmentation that subsequently extended all over the head and anterior part of the trunk. Ventrally there were one or two melanophores on the caudal peduncle, and a series of melanophores on the last myomeres.

The larvae of the two species differed in some features concerning their pigmentation pattern that are summarized in Table 5. Parablennius gattorugine had some melanophores at the anal and dorsal fin rays and a dark spot on the upper lip that forms a line bordering the entire lip, reaching the corners of the mouth, which were not present in $P$. ruber at least until metamorphosis. Besides, there were features that appeared at an earlier stage, and thus a smaller size, in 
Table 3. Ontogenetic events of embryonic development of Parablennius gattorugine $\left(17.50^{\circ} \mathrm{C}-19.50^{\circ} \mathrm{C}\right)$ and of Parablennius ruber $\left(16.00^{\circ} \mathrm{C}-20.00^{\circ} \mathrm{C}\right)$ in order of first appearance: $(1)$ embryo recognizable; $(2)$ cephalic and caudal dilatation: (3) eye lens; (4) brain; (5) notochord differentiation; (6) brain lobes; (7) notochord; (8) myomeres; (9) auditory vesicules; (10) beginning of pigmented eyes; (11) otoliths; (12) tail bud free of the yolk; (13) gut differentiation; (14) median finfold; (15) embryo movements; (16) hatching glands; (17) pectoral fin buds; (18) mouth differentiation; (19) anus visible but closed; (20) mouth visible but closed; (21) anus opened; (22) mouth opened; (23) opercula differentiation; (24) opercula opened; (25) hatching.

\begin{tabular}{|c|c|c|c|c|c|c|c|c|c|c|c|c|c|c|c|c|c|c|c|c|c|c|c|c|c|}
\hline & 1 & 2 & 3 & 4 & 5 & 6 & 7 & 8 & 9 & 10 & 11 & 12 & 13 & 14 & 15 & 16 & 17 & 18 & 19 & 20 & 21 & 22 & 23 & 24 & 25 \\
\hline P. gattorugine & $\mathrm{d}_{1}$ & $\mathrm{~d}_{2}$ & $\mathrm{~d}_{3}$ & $\mathrm{~d}_{3}$ & $\mathrm{~d}_{3}$ & $\mathrm{~d}_{3}$ & $\mathrm{~d}_{3}$ & $\mathrm{~d}_{3}$ & $d_{3}$ & $d_{3}$ & $\mathrm{~d}_{3}$ & $\mathrm{~d}_{3}$ & $\mathrm{~d}_{5}$ & $\mathrm{~d}_{5}$ & $\mathrm{~d}_{5}$ & d6 & $\mathrm{d} 8$ & $\mathrm{~d}_{7}$ & $\mathrm{~d}_{7}$ & $\mathrm{~d} 8$ & $\mathrm{~d} 8$ & $\mathrm{~d}_{9}$ & $\mathrm{~d}_{12}$ & $\mathrm{~d}_{14}$ & $\mathrm{~d}_{15}$ \\
\hline P. ruber & $\mathrm{d}_{1}$ & $\mathrm{~d}_{2}$ & $\mathrm{~d}_{2}$ & $\mathrm{~d}_{2}$ & $\mathrm{~d}_{2}$ & $\mathrm{~d}_{3}$ & $\mathrm{~d}_{3}$ & $\mathrm{~d}_{3}$ & $\mathrm{~d}_{4}$ & $d_{5}$ & $\mathrm{~d}_{5}$ & $\mathrm{~d}_{5}$ & d6 & $\mathrm{d} 8$ & d6 & $\mathrm{d} 8$ & $d_{7}$ & $\mathrm{~d}_{9}$ & d9 & $d_{10}$ & $\mathrm{~d}_{10}$ & $\mathrm{~d}_{14}$ & $\mathrm{~d}_{14}$ & $\mathrm{~d}_{15}$ & $\mathrm{~d}_{16} 6$ \\
\hline
\end{tabular}

Table 4. Ontogenetic events of larval development of Parablennius gattorugine $\left(16.00^{\circ} \mathrm{C}\right)$ and of Parablennius ruber $\left(16.00^{\circ} \mathrm{C}-18.00^{\circ} \mathrm{C}\right)$ in order of first appearance (days after hatching): $(1)$ exogenous feeding; (2) notochord starts to flex; (3) teeth; (4) caudal fin rays; (5) ventral fin buds; (6) pectoral fin rays; (7) segmented caudal fin rays; (8) ossified vertebrae; (9) ventral fin rays; (10) dorsal fin rays; (11) anal fin rays; (12) notochord flexion completed; (13) larvae began to contact the aquarium bottom; (14) head tentacles; (15) most larvae settled on the bottom; (16) juvenile behaviours; (17) typical juvenile pigmentation.

\begin{tabular}{|c|c|c|c|c|c|c|c|c|c|c|c|c|c|c|c|c|c|}
\hline & 1 & 2 & 3 & 4 & 5 & 6 & 7 & 8 & 9 & 10 & 11 & 12 & 13 & 14 & 15 & 16 & 17 \\
\hline \multirow[t]{2}{*}{ P. gattorugine } & $\mathrm{d} 2-3$ & $\mathrm{~d} 8$ & d9 & $\mathrm{d}_{9-12}$ & $\mathrm{~d}_{9-12}$ & $\mathrm{~d}_{10-12}$ & $\mathrm{~d}_{18-19}$ & $\mathrm{~d}_{18-21}$ & $\mathrm{~d}_{19}-21$ & $\mathrm{~d} 20-22$ & $\mathrm{~d}_{21-22}$ & $\mathrm{~d}_{3} \mathrm{O}$ & $d_{31}$ & $d_{57}$ & d66 & d66 & $\mathrm{d}_{96}$ \\
\hline & \multicolumn{6}{|c|}{$5.3-8.0 \mathrm{~mm}$} & \multicolumn{5}{|c|}{$9.2-10.0 \mathrm{~mm}$} & \multicolumn{2}{|c|}{$11.0-12.0 \mathrm{~mm}$} & \multicolumn{4}{|c|}{$18.0-30.0 \mathrm{~mm}$} \\
\hline P. ruber & $\mathrm{d}_{2}-\mathrm{d}_{4}$ & $\mathrm{~d}_{16}$ & $?$ & $\mathrm{~d}_{17}$ & $?$ & $\mathrm{~d}_{22}$ & $?$ & $\mathrm{~d}_{2} 8$ & $?$ & $?$ & $?$ & $d_{53}$ & $\mathrm{~d}_{2} 6$ & $?$ & $\mathrm{~d}_{47}$ & $?$ & $?$ \\
\hline
\end{tabular}




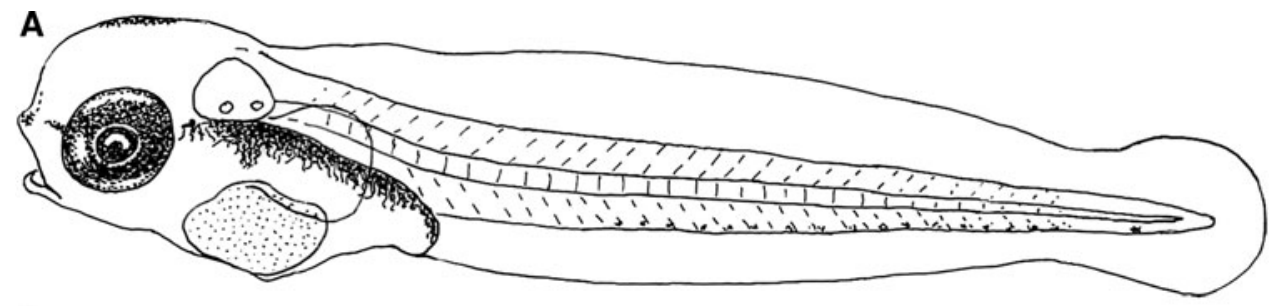

B

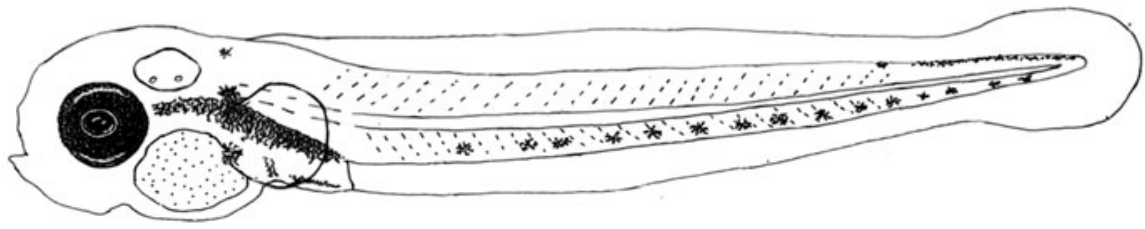

Fig. 1. Newly-hatched larvae. (A) Parablennius gattorugine (5.2 mm TL); (B) Parablennius ruber (4.1 mm TL). Evidence of the melanophores on the head in P. gattorugine.

P. ruber which developed at a later stage in $P$. gattorugine. Interestingly, the newly-hatched larvae of $P$. gattorugine had some melanophores on the head (one to five) (see Figure 1) which although they were absent in the smaller larvae of $P$. ruber, appeared when larvae were more than 5 days, when they reached a similar size $(5.0-6.0 \mathrm{~mm}$ TL). Finally, although both species presented melanophores in the pectoral fins between 6.0 and $8.0 \mathrm{~mm} \mathrm{TL}$, while in P. gattorugine they were confined to the six lower rays of the pectorals (from the base of the lower ray to the middle of the 6th ray) in $P$. ruber they were present between the distal part of all pectoral rays, forming a band along the pectoral fins edge (see Figure 2). This difference in pectoral fin coloration persisted until metamorphosis. Although pectoral fin pigmentation becomes much more extended, the conspicuous darker band persists at the pectoral fin edge of $P$. ruber making the larva clearly distinctive to that of $P$. gattorugine.

The pigmentation pattern of both species was maintained during development, with an increase in the number and conspicuousness of melanophores at the ventral and dorsal row, in front of the liver and at the cephalic region and opercula.

\section{DISCUSSION}

The developmental sequences of the two species described in this note are very similar, which was to be expected since

Table 5. Key differences concerning the pigmentation pattern.

\begin{tabular}{|c|c|c|}
\hline \multirow[t]{2}{*}{ Presence of melanophores } & \multicolumn{2}{|l|}{ Larval total length } \\
\hline & $\begin{array}{l}\text { Parablennius } \\
\text { gattorugine }\end{array}$ & $\begin{array}{l}\text { Parablennius } \\
\text { ruber }\end{array}$ \\
\hline At the base of the pectoral fins & $5.50-7.00 \mathrm{~mm}$ & $4.00-4.10 \mathrm{~mm}$ \\
\hline $\begin{array}{l}\text { At the posterior dorsal half of the } \\
\text { larvae }\end{array}$ & $5.50-7.00 \mathrm{~mm}$ & $4.00-4.10 \mathrm{~mm}$ \\
\hline Between the trunk and the head & $7.00-8.00 \mathrm{~mm}$ & $4.00-4.10 \mathrm{~mm}$ \\
\hline Near the anus & $7.00-8.00 \mathrm{~mm}$ & $4.00-4.10 \mathrm{~mm}$ \\
\hline On the upper lip & $8.50-10.00 \mathrm{~mm}$ & Absent \\
\hline At the anal and dorsal fin rays & $14.00-15.00 \mathrm{~mm}$ & Absent \\
\hline $\begin{array}{l}\text { A complete row over the } \\
\text { notochord }\end{array}$ & $14.00 \mathrm{~mm}$ & $10.00 \mathrm{~mm}$ \\
\hline
\end{tabular}

phylogenetic studies, based on molecular data, indicated that they are sister species (Almada et al., 2005). In this context, it is interesting to note that several differences reported are heterochronic in nature. Some traits appear in both species when they are of similar sizes, but as Parablennius ruber hatched at a smaller size those traits occurred at a later time after hatching in this species. Other traits did not follow this pattern and appeared in each species at a different size. These heterochronic differences in closely related species may provide future avenues to be explored in the context of the genetic mechanisms controlling chromatophore development and migration in larval fish.

Apart from these heterochronic differences, there are however persistent differences that allow unambiguous identification of larvae of both species throughout their entire development. They include larval spination and a conspicuous dark band on the edge of the pectoral fin, which are both present in $P$. ruber and absent in P. gattorugine. Moreover, after the fin rays are visible, one more distinctive feature is available. Parablennius ruber has one more branched ray in the anal fin than $P$. gattorugine ( $P$. ruber has 21 branched fin rays whereas $P$. gattorugine has 20).

The developmental sequence of $P$. gattorugine described in this study agrees, with a few exceptions, with those provided by Ford (1922) and Lebour (1927). In the present study egg size was smaller to that reported by Lebour (1927) $(1.2 \mathrm{~mm}$ versus $1.6 \mathrm{~mm}$ respectively). Lebour (1927) reported a small size for the newly-hatched larvae $(4.9 \mathrm{~mm})$, which is surprising considering that the egg size was larger. She also stated however that the newly-hatched larvae still had a large yolk sac, while ours had almost no yolk sac and were ready to start exogenous feeding. It is possible that the findings described by Lebour (1927) correspond to prematurely hatched larvae. This author used eggs removed from the nest and brought to the laboratory, a condition that especially if coupled with a rise in temperature, often promotes premature hatching.

For $P$. ruber, the egg size and the size of the newly-hatched larvae described in this work were similar to that reported by Villegas-Río et al. (2009) (1.00 versus $1.02 \mathrm{~mm}$ for egg size and 4.10 versus $4.65 \mathrm{~mm}$ for newly-hatched larvae respectively). However, the newly-hatched larvae reported by these authors still had a large yolk sac, the mouth was not completely open and the jaws and lips were not formed, while ours 

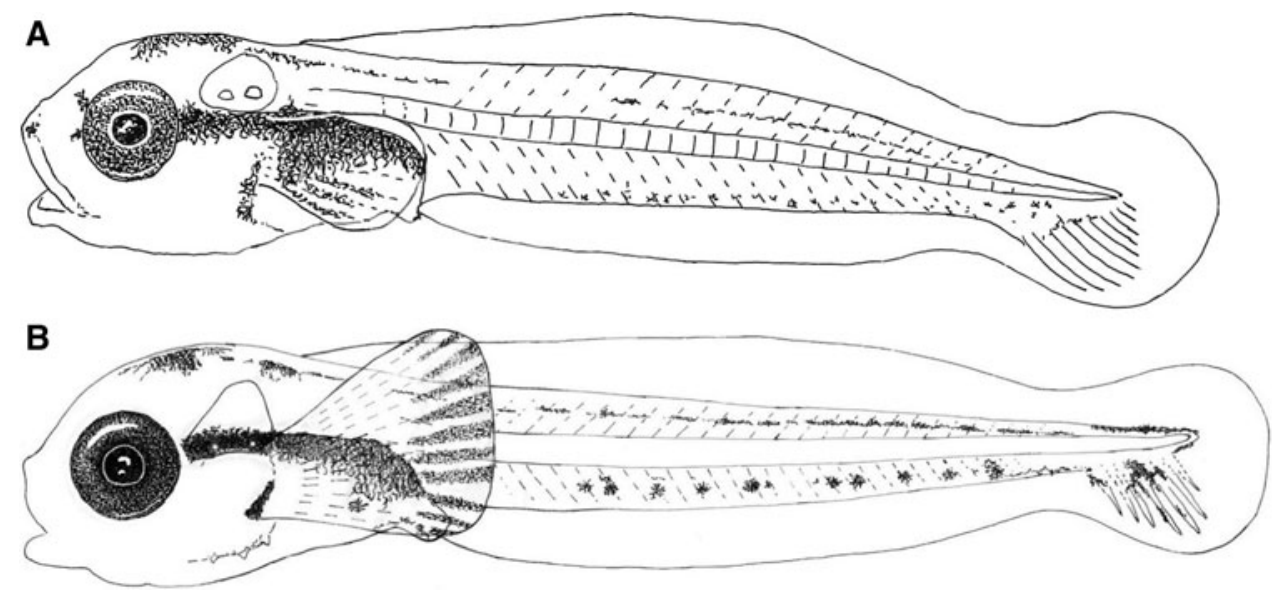

Fig. 2. Larvae with $8.0 \mathrm{~mm}$ TL. (A) Parablennius gattorugine (15 days after hatching); (B) Parablennius ruber (28 days after hatching). Evidence of the darker band at the pectoral fin edge of $P$. ruber absent in P. gattorugine.

had almost no yolk sac and were ready to start exogenous feeding. It is possible that Villegas-Ríos et al. (2009) described a prematurely hatched larva, for the same reasons as Lebour (1927) for P. gattorugine. Hatching of larvae ready or almost ready to start exogenous feeding is the typical condition in blenniids, and was confirmed by the authors in previous studies, in which the eggs were cared for by the males and the temperature was kept at values similar to those prevailing in the sea during the breeding season (e.g. Faria et al., 2006).

The present study unambiguously confirms that the larvae of P. gattorugine do not have pre-opercular spines and present a pattern of chromatophore distribution that corresponds to that described by Ford (1922) and Lebour (1927), and not to the one described by Villegas (1980), who also reported spination on the larvae. Villegas's description agrees with that of $P$. ruber given in this study. Villegas collected larvae from the plankton and it is possible that the larvae of $P$. ruber rather than $P$. gattorugine were taken, since they are so similar.

Recently, Goodwin \& Picton (2007) reported on the occurrence of $P$. ruber on British coasts and provided data which strongly suggest that this species may be, at least in recent years, much more abundant in western European waters than previously assumed. Moreover, if the behavioural differences observed in the present study are confirmed in nature, they mean that while the larvae of $P$. gattorugine are more dispersed in the water column, those of $P$. ruber are likely more abundant near the bottom. All these considerations make the possibility that Villegas (1980) collected larvae of $P$. ruber instead of $P$. gattorugine more probable.

\section{ACKNDWLEDGEMENTS}

This study was supported by the Fundação para a Ciência e Tecnologia (FCT) as part of the Pluriannual Program (UI\&D 331/94 and 531/96, partially FEDER funded) and by FCT and FEDER as part of the project POCTI/BSE/46825/ 2002. C.F. was also supported by a grant from FCT (SFRH/ $\mathrm{BPD} / 26939 / 2006)$. We would like to thank the technicians of Aquário Vasco da Gama for the help in tank maintenance and Rita Lourenço for the figures.

\section{REFERENCES}

Almada V.C., Oliveira R.F., Gonçalves E.J., Almeida A.J., Santos R.S. and Wirtz P. (2001) Patterns of diversity of the north-eastern Atlantic blenniid fish fauna (Pisces: Blenniidae). Global Ecology and Biogeography 10, 411-422.

Almada F., Almada V.C., Guillemaud T. and Wirtz P. (2005) Phylogenetic relationships of the north-eastern Atlantic and Mediterranean blenniids. Biological Journal of the Linnean Society 86, 283-295. DOI:10.1111/j.1095-8312.2005.00519.x

Almada V.C., Domingues V.S., Monteiro N.M., Almada F. and Santos R.S. (2007) Molecular data confirm the validity of the Portuguese blenny (Parablennius ruber, Valenciennes, 1836) and its presence in Western Europe. Journal of Fish Biology 70, 248-254. DOI:10.1111/ j.1095-8649.2007.01397.x

Almeida A.J. (1982) Sur la presence de Blennius ruber Valenciennes, 1836 aux Açores (Pisces, Blenniidae). Cybium 6, 35-40.

Azevedo J.M.N. and Homem N. (2002) Age and growth, reproduction and diet of the red blenny Parablennius ruber (Blenniidae). Cybium $26,129-133$.

Bath H. (1982) Beitrag zur revalidation von Parablennius ruber (Valenciennes, 1836) mit kritschen bemerkungen zur gultigkeit der gattung Pictiblennius Whitley 1930 (Pisces: Blenniidae). Senckenbergiana Biologica 62, 211-224.

Brown E.M. (1929) Notes on the breeding habits and early larvae of the tompot-blenny (Blennius gattorugine). Proceedings of the Zoological Society of London 3, 35-40.

Dunne J. and Byrne P. (1979) Notes on the biology of the tompot blenny, Blennius gattorugine Brunnich. Irish Naturalists' Journal 19, 414-418.

Faria C., Gil F. and Almada V.C. (2006) Ontogenetic development of Parablennius pilicornis (Pisces: Blenniidae) in controlled conditions. Scientia Marina 70, 667-671.

Fives J.M. (1970) Blenniidae of the North Atlantic. Fiches d'Identification des Oeufs et Larves de Poissons CIEM 3, 1-4.

Ford E. (1922) On the young stages of Blennius ocellaris L., Blennius pholis L., and Blennius gattorugine L. Journal of the Marine Biological Association of the United Kingdom 12, 688-692.

Goodwin C.E. and Picton B.E. (2007) The red blenny Parablennius ruber in the British Isles, with notes on field identification characteristics and ecology. Journal of the Marine Biological Association of the United Kingdom 87, 1309-1313. DOI:10.1017/So02531540705744X 
Lebour M.V. (1927) The eggs and newly hatched young of the common blennies from the Plymouth neighbourhood. Journal of the Marine Biological Association of the United Kingdom 14, 647-650.

Santos R.S. (1987) Aspectos da ecologia e comportamento da fauna litoral dos Açores: I-Primeiras observações sobre o comportamento territorial e parental de Parablennius ruber (Valenciennes) (Pisces: Blenniidae), com uma pequena nota sobre os embriões. Açoreana 6, $352-377$.

Villegas M.L. (1980) Postlarvas de blennidos del Mar Cantábrico. Boletin del Instituto Español de Oceanographia VI, 70-93.

Villegas-Ríos D., Martínez A., Palmera A.M. and Azevedo J.L.M. (2009) Early development stages of the red-blenny, Parablennius rubber (Teleostei: Blenniidae). Journal of the Marine Biological Association of the United Kingdom 89, 605-608. DOI:10.1017/ Soo25315408002646

Wheeler A. (1969) The fishes of the British Isles and North-West Europe. London: Macmillan.
Wheeler A.C., Merrett N.R. and Quigley D.T.G. (2004) Additional records and notes for Wheeler's (1992) list of the common and scientific names of fishes of the British Isles. Journal of Fish Biology 65, 1-40. DOI:10.1111/j.0022-1112.2004.00583.x.

and

Zander C.D. (1986) Blenniidae. In Whitehead P.J.P., Bauchot M.L., Hureau J.C., Nielsen J. and Tortonese E. (eds) Fishes of the northeastern Atlantic and the Mediterranean. Paris: UNESCO, pp. $1096-$ 1112.

\section{Correspondence should be addressed to:}

\section{Faria}

Unidade de Investigação em Eco-Etologia

Instituto Superior de Psicologia Aplicada

R. Jardim do Tabaco 34, P-1149-041 Lisboa, Portugal email: cfaria@ispa.pt 